\title{
What to do when the choice is no choice at all? A critical view on nutritional recommendations for CoVID-19 quarantine
}

\author{
Andre Luis Ribeiro Ribeiro $\mathbb{1}^{1} \cdot$ Naama Waléria Alves Sousa ${ }^{1} \cdot$ Vitor Oliveira Carvalho ${ }^{2}$
}

Received: 11 May 2020 / Revised: 30 May 2020 / Accepted: 4 August 2020 / Published online: 14 August 2020

(c) Springer Nature Limited 2020

\section{To the Editor:}

Indeed, since the outbreak of the COVID-19 epidemic in late 2019, the world has turned upside down. The situation has generated a wide panic state, from the global economy, health systems, and, consequently, in people's life. So far, the best measure to face this high transmissible virus (SARS-COV-2) is social distancing, which has been responsible to flatten the curve of new cases and deaths. However, social distancing can have many side effects, such as anxiety and stress at the population level.

Based on that, we have read with great joy the paper published by Muscogiuri et al. [1], in which the authors call the attention to nutritional habits under stressful conditions and recommended some food options that good sources of immuno-supportive nutrients, to balance the negative effects of social distancing. This paper has an important taking-home message: how people's choice can have substancial influence in many aspects of their own lives. Summarizing the manuscript, by making the right food choices, individuals can strength their immune system to be more alert against pathogens invasion and also help immune cells to tackle acquired infections, such as the COVID-19. On the other hand, the defined "food craving," particularly the carbohydrate craving, is correlated with weight gain and obesity, which links to chronic inflammation, heart diseases,

Andre Luis Ribeiro Ribeiro

andre.ribeiro.13@ucl.ac.uk

1 Oral and Maxillofacial Surgery, INCOM-Instituto de Cirurgia Oral e Maxilofacial, Rua Municipalidade 985, Umarizal, Belém, PA 66050-350, Brazil

2 Department of Physical Therapy, Postgraduate Program in Health Science (The GrEAt Group-Grupo de Estudos em Atividade Fisica), Federal University of Sergipe (Universidade Federal de Sergipe-UFS), Av. Marechal Rondon, s/n - Jardim Rosa Elze, São Cristóvão - SE, Sergipe 49100-000, Brazil and diabetes, all associated with potential poorer prognosis and higher mortality rates in COVID-19 patients.

The authors state that most of the key ingredients for healthy nutrition are found in Mediterranean cuisine, which are supposedly accessible to people. However, every coin has two sides. Currently, Brazil is on the way to become the new epicenter of the COVID-19 pandemic [2] and is one of the largest agricultural exporters in the world. Nevertheless, most of the Brazilian population has no option to choose what they want to eat, limiting their choices to the few items they might afford to buy.

The COVID-19 pandemic has shown the huge inequality in Brazil. While the world economy collapsed, a chain reaction of negative effects made the life of poor people even harder. For instance, unemployment is reaching the highest records level, food prices are rising while the country's economy is in important deflation [3]. Moreover, the US dollar (USD) is in its historic highest exchange rate, and social distancing in the residency of poor people, the so-called favelas, is almost impossible. Breakdown this information, the government is proud to say that the food producers are carrying the Brazilian economy, since exportation now is very inviting once the world demand is high, the currency exchange rate is very attractive, and whatever remains in the country is overpriced.

The informal market is the main occupation of many Brazilians, and as a consequence of the quarantine, they are making no money, while many others got fired due to the market crash. So far, the governmental financial support reached less than $10 \%$ of the population, providing 600 Brazilian reais monthly to qualified people, which is equivalent to a bit more than 100 USD monthly to pay all the expenses. In favelas, most of the residences need to accommodate families with an average rate of five individuals per room, with a population density in favelas around $10 \times$ more than the rest of the city [4]. The extremely highdensity housing is another issue, sanitation is very poor in these areas, with the water supply running out daily. These conditions make social distancing an unworkable theory 
and current information shows the favelas with the highest death rate in the country.

Regarding to diet, with the money left after paying for other fundamental bills, the only food that these people can afford are carbohydrate rich and nutritional poor groceries. Their diet is based on cassava flour, rice, and refined pasta. Many vegetables are expensive as well as protein sources, which is a great contradiction since Brazil is an important food and protein exporter. Taken together, the observations about these poor people and their living conditions put them among the most vulnerable ones to SARS-CoV-2 infection [4].

Although we know that these problems are quite complex, we need to rethink how we will reborn as a society after overcoming this pandemic. SARS-CoV-2 is now transmitted human to human, and unless people live forever in social distancing without taking care of each other, the risk of another pandemic will be always a threat.

\section{Compliance with ethical standards}

Conflict of interest The authors declare that they have no conflict of interest.
Publisher's note Springer Nature remains neutral with regard to jurisdictional claims in published maps and institutional affiliations.

\section{References}

1. Muscogiuri G, Barrea L, Savastano S, Colao A. Nutritional recommendations for CoVID-19 quarantine. Eur J Clin Nutr. 2020. https://doi.org/10.1038/s41430-020-0635-2.

2. Magalhaes L, Sciaudone C. Coronavirus sweeps across Brazil, a land ill-equipped to fight it. The Wall Street Journal, Dow Jones \& Company; 2020. www.wsj.com/articles/coronavirus-sweeps-a cross-brazil-a-land-ill-equipped-to-fight-it-11588603847. Accessed 11 May 2020.

3. Instituto brasileiro de geografia e estatística-IBGE. IPCA Foi De $-0,31 \%$ Em Abril. Instituto brasileiro de geografia e estatística. 2020. https://agenciadenoticias.ibge.gov.br/agencia-sala-deimprensa/2013-agencia-de-noticias/releases/27615-ipca-foi-de0-31-em-abril. Accessed 11 May 2020. (Website in Portuguese).

4. Ribeiro, MJ. Junto e Misturado. Data Labe. 2020. https://datalabe. org/junto-e-misturado-isolamento-e-quarentena-sao-possiveis-nasfavelas/. Acessed 11 May 2020. (Website in Portuguese). 